\title{
Establishment of conditioned taste aversions with a 24-hour CS-US interval
}

\author{
FRANK ETSCORN and RONALD STEPHENS \\ Western Kentucky University, Bowling Green, Kentucky 42101
}

\begin{abstract}
Two experiments were conducted investigating the effects of a 24-h CS-US interval in taste aversion learning. In the first experiment, male albino rats were allowed to consume a nonpreferred CS (HCL-flavored water) and injected, intraperitoneally, $24 \mathrm{~h}$ later with an illness-inducing drug (cyclophosphamide). After two such pairings, the animals exhibited an aversion to the flavored water. In Experiment II, female rats were exposed to the same US $24 \mathrm{~h}$ following consumption of a preferred CS (saccharin-flavored water). However, after only one such pairing, experimental Ss avoided the flavored water and preferred normal tap water in a two-bottle choice situation, while saline-injected controls preferred the saccharin-flavored water to the plain tap water. Due to the controversial nature of conditioning with such long delays of reinforcement, a systematic replication of Experiment II was conducted with male rats, and again an aversion was established to the saccharin-flavored water.
\end{abstract}

Studies in taste aversion learning typically involve presenting an animal with a novel-tasting substance (CS) and, after a period of time, following it with an illness inducer such as drug injection (US). After allowing the animal to recuperate from the illness, it can be observed that the particular CS will be avoided if it is once again presented to the animal. Research in this area is particularly interesting with respect to the long delays of reinforcement that have been effectively used in the establishment of aversions. Revusky (1968), using a $20 \%$ sucrose solution for his CS, demonstrated aversions with a 7-h CS-US interval. The US was $50 \mathrm{R}$ of X-irradiation. Smith and Roll (1967) gave evidence for a 12-h delay of reinforcement using saccharin as a CS. Their US consisted of a 100-R dose of X-ray. Further evidence for a 12-h delay was found by Stephens and Etscorn (1972) using saccharin (CS) and Cytoxan ${ }^{\circledR}$ for the US $(100 \mathrm{mg} / \mathrm{kg}$ of $\mathrm{S}$ weight). However, while the first two experiments used rats, Stephens and Etscorn used mice. Furthermore, the mice in the final experiment were maintained entirely on distilled water for the duration of the design (11 days).

The present experiments were conducted with the purpose of expanding the findings of the above-mentioned studies and to investigate the possibility of establishing a $24-\mathrm{h}$ CS-US interval in a taste-aversion paradigm.

\section{EXPERIMENT I}

\section{Method}

Ss were four male albino rats, averaging $349 \mathrm{~g}$ in weight, drawn from the Western Kentucky University animal colony. On March 4, all Ss were housed individually in wire mesh cages without water; they were given free access to Purina Lab Chow for the duration of the experiment. Laboratory temperature was maintained at a constant $75^{\circ} \mathrm{F}$, and an automatic diurnal cycle was used $(12 \mathrm{~h}$ on, $12 \mathrm{~h}$ off). On March 5, a 6-day adaptation period (Days 1-6) was initiated, which consisted of allowing each animal to drink from an individual drinking tube for $10 \mathrm{~min}$ each day at 1 p.m. All animals were assigned two sets of individual tubes (one for the CS and one for distilled water) and stainless steel spouts for control purposes. Drinking bottles were attached to the front of each cage, enabling the spouts to enter at the center of the cage fronts, 1 in. from the bottom. All bottles were filled with $30 \mathrm{cc}$ of the appropriate fluid during the experiment. Distilled water $\left(78^{\circ} \mathrm{F}\right)$ was used throughout adaptation and all ensuing days. Following the 10 -min allotted consumption period each day, the drinking tubes were removed and the amount consumed per $S$ was measured and recorded. At 1 p.m. on Day 7, all Ss were given access to the CS $(.20 \mathrm{cc}$ of $28 \% \mathrm{HCL}$ in $200 \mathrm{cc}$ of distilled water) for $10 \mathrm{~min}$, and again the amount consumed per animal was recorded. At this time, Ss were weighed and dosages were computed for the US $(100 \mathrm{mg} / \mathrm{kg}$ of S weight of cyclophosphamide, Cytoxan ${ }^{\circledR}$, Meade-Johnson Laboratories, Evansville, Indiana). Twenty-four hours following removal of the CS, all animals were injected IP (27-ga needles) with the US. The injection procedure (removal of the $S$ from cage, hand-held injection, and returning animal) averaged approximately $25 \mathrm{sec}$ per animal. Immediately following injection procedures, Ss were allowed to drink distilled water for 10 min. Days 9 and 10 were recovery days, in which the animals were given access to distilled water on the normal 10-min schedule. Day 11 consisted of presenting the same CS for $10 \mathrm{~min}$ as on Day 7 and again recording consumption. The procedure on Day 12 was identical to that of Day 8 (US administration followed by $10 \mathrm{~min}$ access to water). Days 13 and 14 were recovery days in which Ss were allowed to drink water on the regular 10 -min schedule. Day 15 merely consisted of presenting the $\mathrm{CS}$ and recording consumption.

\section{Results}

As depicted in Fig. 1, there was a marked decrease in fluid consumption on the final day (Day 15). Group means, in ccs consumed, for each CS day were, respectively, $12.75,11.5$, and 6.75. Comparison of CS consumption on these 3 days yielded a difference of $\mathrm{p}<.042$ (Friedman two-way ANOVA). Consumption did not differ significantly between the first 2 CS days; however, individual comparisons between the last CS day with each of the first 2 CS days indicated substantial changes ( $p<.05$ for both comparisons). 


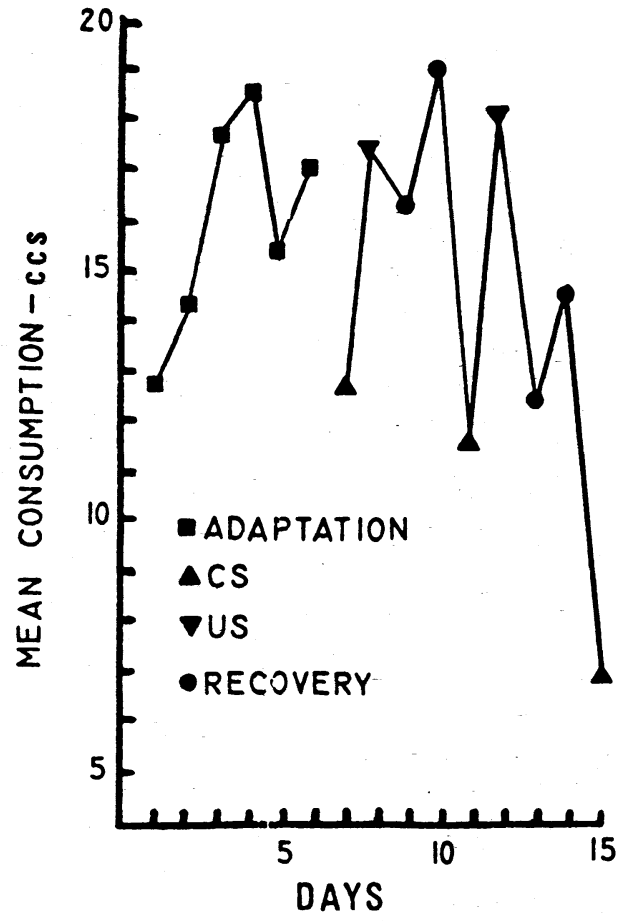

Fig. 1. Mean intake of distilled water during adaptation, treatment, and recovery.

\section{Discussion}

Although an aversion did appear to be established to the HCL-flavored water, recent studies have indicated that a more sensitive method in taste-aversion research involves using a two-bottle choice situation as described by Dragoin (1971). Another design feature also caused concern over the present findings. As distilled water was used throughout the experiment, it was speculated that this factor could have contributed to the findings above. Indeed, it was felt that some inherent taste factor in the distilled water itself could have been responsible.

\section{EXPERIMENT II}

With possible questions regarding the findings of Experiment I, the following experiment centered on addressing the above-mentioned issues.

\section{Method}

On November 2, 10 female albino rats, averaging $207 \mathrm{~g}$ in weight, were selected randomly from the university animal colony. All Ss were housed in indivudal cages without water but with free access to Purina Lab Chow for the duration of the experiment. On Day 1 (November 3), all animals were introduced to a drinking schedule consisting of $10 \mathrm{~min}$ access to tap water, beginning at 1 p.m. daily for 6 days. As the two-bottle preference test was to be used to ascertain the presence of an aversion, water during adaptation was presented in two drinking bottles, with the order of insertion varied (RLLRRL) in order to eliminate any position effect. Pilot studies had indicated that this method was as effective as using one bottle with water and one empty in the adaptation period. Bottles, cages, and lab conditions were identical to those of Experiment I. On Day 7
(CS day), Ss were divided randomly into two equal groups: Group 1 (experimental) or group 2 (control). Both groups were then given $10 \mathrm{~min}$ access to the CS $(1 / 2$ grain saccharin in $200 \mathrm{cc}$ of tap water) presented in both drinking bottles, which were inserted into the cages at the same time. All bottles during the course of the experiment were filled with $30 \mathrm{cc}$ of the appropriate fluid. Following the allotted $10 \mathrm{~min}$, the amount consumed per $\mathrm{S}$ for both groups was measured and recorded (consumption measures were also taken for each $S$ on all adaptation days and recovery days). At this time, experimental Ss were weighed in order to calculate their US dosage (cyclophosphamide at an intensity of $100 \mathrm{mg} / \mathrm{kg}$ of S weight). On Day 8 at 1:10 p.m. ( $24 \mathrm{~h}$ following removal of the CS), all experimental Ss were injected IP with the US, using the procedure described in Experiment I. Likewise, control Ss were also injected IP with equivalent volumes of normal saline solution. Following injection, however, Ss were not given their daily water ration in order to control for any possible association between illness and water taste. On Days 9.and 10, all animals were simply allowed to consume water on the regular $10 \mathrm{~min}$ per day schedule. On Day 11 (test day), both groups of Ss were given access for $1 \mathrm{~h}$ to one bottle containing the CS and one containing tap water. Saccharin and water bottle positions were randomized and both bottles were inserted at the same time. Following the allotted time period, consumption measures were taken for each S.

\section{Results}

The results (as depicted in Table 1 and Fig. 2) indicate that an aversion was established to the saccharin CS in the experimental animals, while control animals demonstrated a clear preference for saccharin over the tap water. Analysis was conducted by comparing the magnitudes of difference for experimentals with those for controls (subtracting individual saccharin consumption measures on Day 11 from individual saccharin consumption on Day 7 for both groups). The mean magnitude of difference was 11.12 for experimentals and 2.06 for controls. A between-groups comparison of individual magnitudes of difference yielded $\mathrm{p}<.004$ (Mann-Whitney U). For Day 11, experimentals demonstrated a saccharin preference index (total saccharin consumption/total liquid consumption $\times 100$ ) of 32 , while controls showed an index of 85 .

Table 1

Liquid Consumption in Cubic Centimeters for Experimental and Control Ss on Day 7 (CS Day) and Day 11 (Test Day)

\begin{tabular}{|c|c|c|c|c|c|c|}
\hline \multicolumn{4}{|c|}{ ental } & \multicolumn{3}{|c|}{ Control } \\
\hline & \multirow{2}{*}{$\frac{\text { Day } 7}{\mathrm{CS}}$} & \multicolumn{2}{|c|}{ Day 11} & \multirow{2}{*}{$\frac{\text { Day } 7}{\mathrm{CS}}$} & \multicolumn{2}{|c|}{ Day 11} \\
\hline & & $\mathrm{CS}$ & $\mathrm{H}_{2} \mathrm{O}$ & & $\mathrm{CS}$ & $\mathrm{H}_{2} \mathrm{O}$ \\
\hline & $\begin{array}{l}17.5 \\
19.8 \\
11.9 \\
16.7 \\
17.0\end{array}$ & $\begin{array}{r}5.9 \\
10.6 \\
1.7 \\
7.1 \\
2.0\end{array}$ & $\begin{array}{r}13.9 \\
1.9 \\
11.1 \\
7.7 \\
18.9\end{array}$ & $\begin{array}{l}18.2 \\
18.4 \\
17.4 \\
17.7 \\
17.0\end{array}$ & $\begin{array}{l}14.8 \\
17.7 \\
15.5 \\
16.2 \\
14.5\end{array}$ & $\begin{array}{l}2.0 \\
1.0 \\
3.4 \\
2.8 \\
4.0\end{array}$ \\
\hline $\begin{array}{l}\text { Total } \\
\text { Mean }\end{array}$ & $\begin{array}{l}82.9 \\
16.6\end{array}$ & $\begin{array}{r}27.3 \\
5.5\end{array}$ & $\begin{array}{l}53.5 \\
10.7\end{array}$ & $\begin{array}{l}88.7 \\
17.7\end{array}$ & $\begin{array}{l}78.6 \\
15.7\end{array}$ & $\begin{array}{r}13.2 \\
2.6\end{array}$ \\
\hline
\end{tabular}




\section{DISCUSSION}

The hypothesis that a conditioned taste aversion can be established using a 24-h CS-US interval is supported by the results of the present experiments. Furthermore, it appears that the unusually long delay of reinforcement is effective in rats when using either preferred (saccharin) or nonpreferred (HCL) CS solutions. As female rats were used in Experiment II, a replication of the design using male Ss was conducted, which yielded virtually identical results. Moreover, in an attempt to eliminate any unintentional associations, Experiment II animals were not allowed their daily ration of water following their US injection. In the replication of

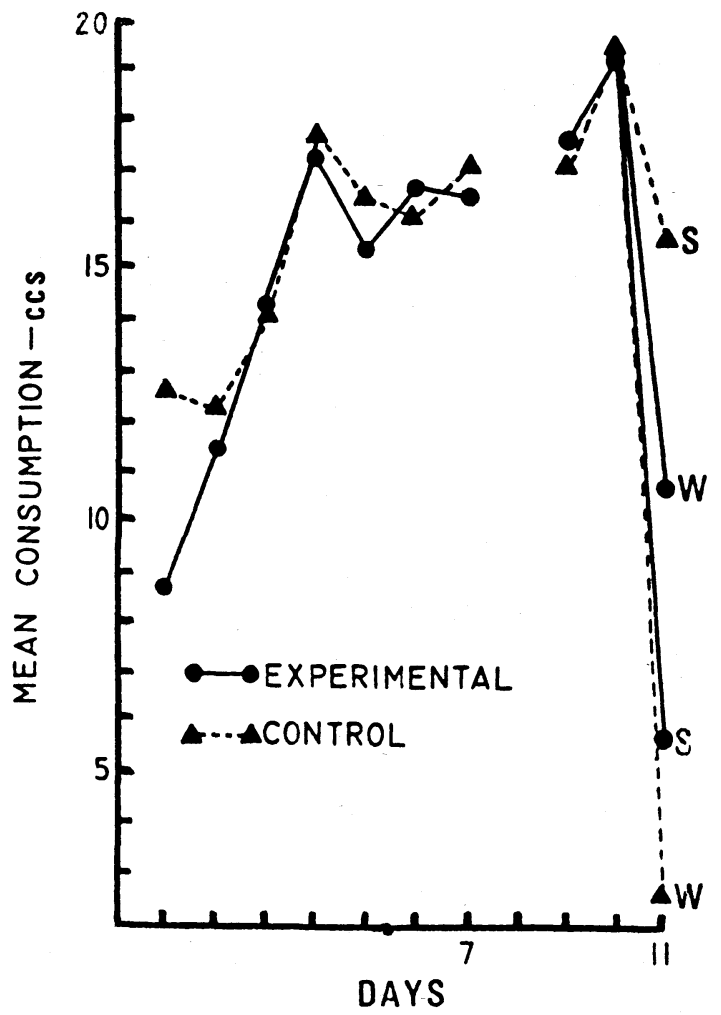

Fig. 2. Mean intake of tap water during adaptation (Days 1-6), during CS administration (Day 7), during recovery (Days 9 and 10), and during two-bottle preference test (Day 11) with water (W) and saccharin (S) for Group 1 (experimental) animals and Group 2 (controls). No fluids were given on Day 8 for control purposes.
Experiment II, this procedure was eliminated (i.e., replication Ss were allowed to drink immediately upon replacement into their home cages following the US injection). Again, this exerted no significant effect, as the animals drank, on the average, as much on their first recovery day as they did on their last adaptation day. Also, it was noted that consumption of Lab Chow remained constant throughout the design, indicating no aversion to the familiar diet. In previous experiments by these researchers, it had been noted that when novel and distinctively flavored Rat Chow was used as the CS, animals would, when retested, scatter rather than hoard their chow. This scattering was not observed in any of the experiments using a liquid CS.

Initially, questions were raised by these authors concerning the high dosages of the US. It was felt that due to its toxic effects, true taste aversion was not occurring but simply a general depression in the animals' behavior resulting in decreased liquid consumption. However, it can be seen from Table 1 that the US caused no general depression in the experimental group, as in only two cases did the animals consume less on the test day than on Day 7. Also, it might be added that five Ss run as sensitization controls were used but not included in the reported data. These animals simply received water on Day 7 with cyclophosphamide injections following on Day 8. They were tested by being given access to the CS on test day; however, no sensitization was observed, nor was there any general depression of total fluid intake from Day 7 to Day 11 noted in any of the five animals.

\section{REFERENCES}

Dragoin, W. B. A comparison of two methods of measuring conditioned taste aversions. Behavioral Research Methods \& Instrumentation, 1971, 3, 309-310.

Revusky, S. H. Aversion to sucrose produced by contingent X-irradiation: Temporal and dosage parameters. Journal of Comparative \& Physiological Psychology, 1968, 65, 17-22.

Smith, J. C., \& Roll, D. L. Trace conditioning with X-rays as the aversive stimulus. Psychonomic Science, 1967, 9, 11-12.

Stephens, R. M., \& Etscorn, F. T. Bait-shyness in mice with a 12-hour CS-US interval. Paper presented at the Kentucky Psychological Association, Barren River, November 1972.

(Received for publication February 5, 1973; revision accepted April 24, 1973.) 